\title{
Composition, digestibility and particle-associated enzyme activities in rumen digesta as influenced by particle size and time after feeding
}

\author{
P. Huhtanen', P. Dakowski ${ }^{2}$ and Aila Vanhatalo ${ }^{3}$ \\ 1 Departament of Animal Science, University of Helsinki, \\ SF-00710 Helsinki, Finland \\ 2 The Kielanowski Institute of Animal Physiology and Nutrition, \\ Polish Academy of Sciences, 05-110 Jabtonna, Poland \\ 3 Institute of Animal Production, Agricultural Research Centre, \\ $S F-31600$ Jokioinen. Finland
}

(Received 6 November 1992: accepted 14 December 1992)

\begin{abstract}
Three bulls were given twice daily a diet of grass silage and barley (70:30) on a DM basis. Manual evacuation of rumen contents was made before feeding $, 3,6$ and $9 \mathrm{~h}$ after leeding. The interval between two subsequent evacuations was $27 \mathrm{~h}$. Particle size distribution in the digesta was determined by wet-sieving. The greatest diurnal variation in ruminal NDF pool occurred in the 3-mm fraction. Small particles $(0.04-0.2 \mathrm{~mm})$ contained less NDF and cellulose and more ADL compared with larger particles. Potential NDF digestibility determined by $288 \mathrm{~h}$ nylon bag incubation declined as particle size decreased except for the $0.04-\mathrm{mm}$ fraction. NDF digestibility was positively correlated with the proportion of cellulose in NDF and negatively with that of ADL and hemicellulose. Chemical composition of rumen particulate DM was comparatively unaffected by the time after feeding but NDF digestibility decreased with time when averaged across particle sizes. Particle-associated CMCase and xylanase activities increased gradually as the particle size decreased. The activities were 3 to 9 -fold higher in the $0.04-\mathrm{mm}$ fraction than in the other four fractions. There was a close positive relationship between enzyme activities and content of neutral-detergent solubles in particles.
\end{abstract}

KEY WORDS: Rumen digesta, particle size, chemical composition, enzyme activity

\section{INTRODUCTION}

It is generally accepted that feed particles can only leave the rumen after reduction of particulate matter below a critical size (Poppi et al., 1980; Ulyatt et al., 1986). Feed is broken down physically by ingestive mastication and rumination. Particle size reduction by microbial fermentation alone is minor (Murphy and Nicoletti, 1984) but microbial digestion renders the plant material more sensitive to rumination. Rates of particle size reduction, fermentation and 
passage are the major constraints describing digesta kinetics in the rumen. These processes affect rumen fill, feed intake and fermentation end-products.

Microbial attachment to fibrous substrates is an important prerequisite of the degradation of these substrates in the rumen (Cheng et al., 1984). The adherent microbial population may comprise $70-80 \%$ of the microbial organic matter (Craig et al., 1987), and there is a close relationship between the rate of digestion of fibre and quantity of adherent bacteria (Gerson et al., 1988) or particle-associated enzyme activities (Silva et al., 1987; Huhtanen and Khalili, 1992). Particle-associated microbial population is dependent on available attachment sites, and is affected by rumen environment (Forsberg and Lam, 1977; Silva et al., 1987; Huhtanen and Khalili, 1992). However, there is little information on distribution of the adherent population relative to particle size or particle composition. Gerson et al. (1988) reported a greater microbial density in small particles than in large particles of meadow hay.

The objectives of the present study was to determine the quantity and distribution of NDF among different particle size fractions, and also between digestible and indigestible fractions. The chemical composition, digestibility and particle-associated enzyme acitivies as influenced by particle size and time after feeding were determined with a view toward improving the understanding of their possible significance with respect to rumen function dynamics.

\section{MATERIAL AND METHODS}

\section{Animals and diets}

Three Friesian bulls (mean live weight $520 \mathrm{~kg}$ ), each fitted with a rumen cannula, were used. The experimental diet consisted of grass silage made from timothy (Phleum pratense) and barley in the ratio of 70:30 on a DM basis.

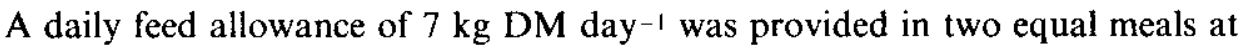
7 a.m. and 7 p.m. The animals were kept in individual standings and had free access to water. A commercial mineral mixture $\left(100 \mathrm{~g} \mathrm{day}^{-1}\right)$ was given to meet the animals' requirements.

\section{Experimental procedure}

The experimental measurements were carried out after an adaptation period of $21 \mathrm{~d}$. Rumen pool size of total digesta was measured by manually removing all the rumen contents. Measurements were made at 7,10,13 and $16 \mathrm{~h}$ on four consecutive days. The time interval between each emptying was therefore $27 \mathrm{~h}$. In later studies (unpublished) this procedure had no effect on rumen microbial activity as indicated by a similar degradation of hay DM in $24 \mathrm{~h}$ before and 
during the 3-d rumen evacuation period. Rumen contents was weighed, thoroughly mixed, sampled and returned to the rumen. Each sample was divided into two subsamples of which one was used for determination of DM content and subsequently for NDF, ADF and ADL analyses. The other subsample was used for particle size analyses and enzyme assays.

Rumen digesta was fractioned into various particle size groups using a wet-sieving technique. The sample $(60 \mathrm{~g}$ wet weight) was first sieved using screens (diameter $20 \mathrm{~cm}$ ) with mesh sizes $3.0,1.0$ and $0.5 \mathrm{~mm}$. The slurry passed through the screens was then filtered through two nylon bags (pore sizes 200 and $40 \mu \mathrm{m}$ ). The bag of larger pore size (external dimensions $6 \times 12 \mathrm{~cm}$ ) was placed within the bag of smaller pore size (external dimensions $8 \times 16 \mathrm{~cm}$ ). The tops of the bags were tied with a tube of running tap water. During rinsing the bags were occasionally squeezed. All particle size distribution measurements were made in triplicate.

Immediately after rumen evacuation one sample of rumen contents was sieved, using a similar procedure as described above, in order to measure enzyme-activities of microbes firmly attached to rumen particles. After sieving, the material was transferred quantitatively into nylon bags (pore size $40 \mu \mathrm{m}$ ), washed under running tap water and squeezed thoroughly by hand. For determination of particle-associated carboxymethylcellulase (CMCase) and xylanase activities, a sample of $1.0 \mathrm{~g}$ of each particle size fraction was used. The details of enzyme extraction and enzyme assays are described by Silva et al. (1987) and Huhtanen and Khalili (1992). The DM content of the particles was determinend in duplicate. Enzyme activities were expressed as $\mu$ mol reducing sugars produced per minute per g DM under the contidions used. The activities were corrected for the substrate breakdown during the extraction procedure.

Rumen particulate fractions of different size $(>3,1-3,0.5-1,0.2-0.5$ and $0.04-0.2 \mathrm{~mm}$ ) were analyzed for NDF, ADF and ADL according to Goering and Van Soest (1970). Cellulose (C) was calculated as ADF-ADL, and hemicellulose (HC) as NDF-ADF. Potential digestibility of DM, NDF (NDFD) and ADF (ADFD) of the rumen contents and each particle size group was determined by $288-\mathrm{h}$ ruminal incubation in nylon bags (pore size $40 \mu \mathrm{m}$ ). The residues were analyzed for NDF and ADF. The undegraded residues were considered to be indigestible NDF (INDF). Digestible NDF (DNDF) was calculated as total NDF-INDF.

\section{Statistical analyses}

The model used to analyze rumen pool size data was: $A_{i}+H_{j}+e_{i j}$, where $\mathrm{A}$ and $\mathrm{H}$ are the effects of animal and evacuation time. For some parameters, the effect of time was further separated into single degree comparisons using 
polynomial contrasts. The model used to analyze composition, degradability and enzyme activities of rumen particles was: $A_{i}+H_{j}+e_{i j}+S_{k}+(A S)_{i k}+$ $(\mathrm{HS})_{j \mathrm{k}}+\mathrm{e}_{\mathrm{ijk}}$, where $\mathrm{A}, \mathrm{H}$ and $\mathrm{S}$ are the effects of animal, time and particle size, and $\mathrm{e}_{\mathrm{ij}}$ and $\mathrm{e}_{\mathrm{ijk}}$ are main plot $(6 \mathrm{df})$ and sub-plot $(24 \mathrm{df})$ errors. Correlation coefficients between chemical composition, NDFD and enzyme acitivities were calculated.

\section{RESULTS}

The silage used contained $207 \mathrm{~g} \mathrm{DM} \mathrm{kg}^{-1}$ and $24.6 \mathrm{~g} \mathrm{~N}, 520 \mathrm{~g} \mathrm{NDF}$ and 281 $\mathrm{g} \mathrm{ADF} \mathrm{kg-1}^{-1} \mathrm{DM}$. The corresponding values for barley were $871,21.1,187$ and 46 , respectively. The silage was of high quality in terms of low $\mathrm{pH}(3.73)$ and low concentrations of fermentation acids and ammonia $\mathbf{N}$.

The amount of rumen digesta decreased from $55.2 \mathrm{~kg}$ at $3 \mathrm{~h}$ to $39.0 \mathrm{~kg}$ at 12 $\mathrm{h}$ after feeding (linear trend $\mathrm{P}<0.001$ ) (Table 1). As diurnal variation in digesta composition was small, differences in the pool size of DM and cell wall constituents were similar to those in the total digesta. The reduction in the total weight of DM occurred in two phases with an initial rapid loss during the first

TABLE 1

The effect of time after feeding on the pool size of rumen digesta, dry matter (DM), distribution of $\mathrm{DM}$ in various particle groups and pool size of cell wall constituents

\begin{tabular}{|c|c|c|c|c|c|c|c|c|}
\hline & \multicolumn{4}{|c|}{ Time after feeding $(\mathrm{h})$} & \multirow{2}{*}{ SEM } & \multicolumn{3}{|c|}{ Significance of effect } \\
\hline & 3 & 6 & 9 & 12 & & Linear & Quadr. & Cubic \\
\hline Total digesta $(\mathrm{kg})$ & 55.2 & 50.4 & 44.8 & 39.0 & 1.41 & $* * *$ & NS & NS \\
\hline Total DM (g) & 5819 & 5245 & 4784 & 3950 & 163 & $* * *$ & NS & NS \\
\hline \multicolumn{9}{|c|}{ Distribution of DM (g) } \\
\hline$>3.0 \mathrm{~mm}$ & 1853 & 1665 & 1313 & 787 & 70.5 & $* * *$ & $\dagger$ & NS \\
\hline $1.0-3.0 \mathrm{~mm}$ & 475 & 424 & 315 & 280 & 44.6 & $*$ & NS & NS \\
\hline $0.5-1.0 \mathrm{~mm}$ & 301 & 245 & 246 & 255 & 20.9 & NS & NS & NS \\
\hline $0.2-0.5 \mathrm{~mm}$ & 487 & 518 & 433 & 612 & 40.1 & NS & NS & + \\
\hline $0.04-0.2 \mathrm{~mm}$ & 585 & 457 & 411 & 383 & 25.7 & $* *$ & + & NS \\
\hline$<0.04 \mathrm{~mm}$ & 2117 & 1936 & 2066 & 1632 & 60.5 & $* *$ & $\dagger$ & $*$ \\
\hline \multicolumn{9}{|c|}{ Cetl wall components (g) } \\
\hline NDF & 3155 & 2708 & 2476 & 2072 & 134.4 & $* *$ & NS & NS \\
\hline ADF & 1506 & 1291 & 1131 & 920 & 75.2 & $* * *$ & NS & NS \\
\hline ADL & 153 & 142 & 135 & 122 & 6.4 & $* *$ & NS & NS \\
\hline Cellulose & 1352 & 1149 & 996 & 798 & 70.7 & $* * *$ & NS & NS \\
\hline Hemicellulose & 1649 & 1416 & 1344 & 1152 & 69.0 & $* *$ & NS & NS \\
\hline
\end{tabular}

SEM $=$ standard error of means

Significance: $\uparrow(\mathrm{P}<0.10) ; *(\mathrm{P}<0.05) ;{ }^{* *}(\mathrm{P}<0.01) ; * * *(\mathrm{P}<0.001)$ 
$3 \mathrm{~h}$ after feeding followed by a more gradual decline between $3-12 \mathrm{~h}$ after feeding. The rate at which DM left the rumen was $548 \mathrm{~g} \mathrm{~h}^{-1}$ between $0-3 \mathrm{~h}$, and $208 \mathrm{~g} \mathrm{~h}^{-1}$ between 3 and $12 \mathrm{~h}$. The amount of DM leaving the rumen over the first $3 \mathrm{~h}$ after feeding was calculated as follows: the amount of DM present in the rumen at $3 \mathrm{~h}$ was subtracted from the sum of DM present before feeding and that ingested. The greatest decrease in rumen DM pool occurred in the 3-mm fraction accounting for $57 \%$ of the total amount of DM disappeared between 3-12 $\mathrm{h}$ after feeding.

The changes in the particle size distribution with time after feeding is shown in Fig. 1. There was a reduction in the $3-\mathrm{mm}$ fraction and generally an inrease in the 0.2 - and $<0.04-\mathrm{mm}$ fractions with time but very little change occurred in other fractions.

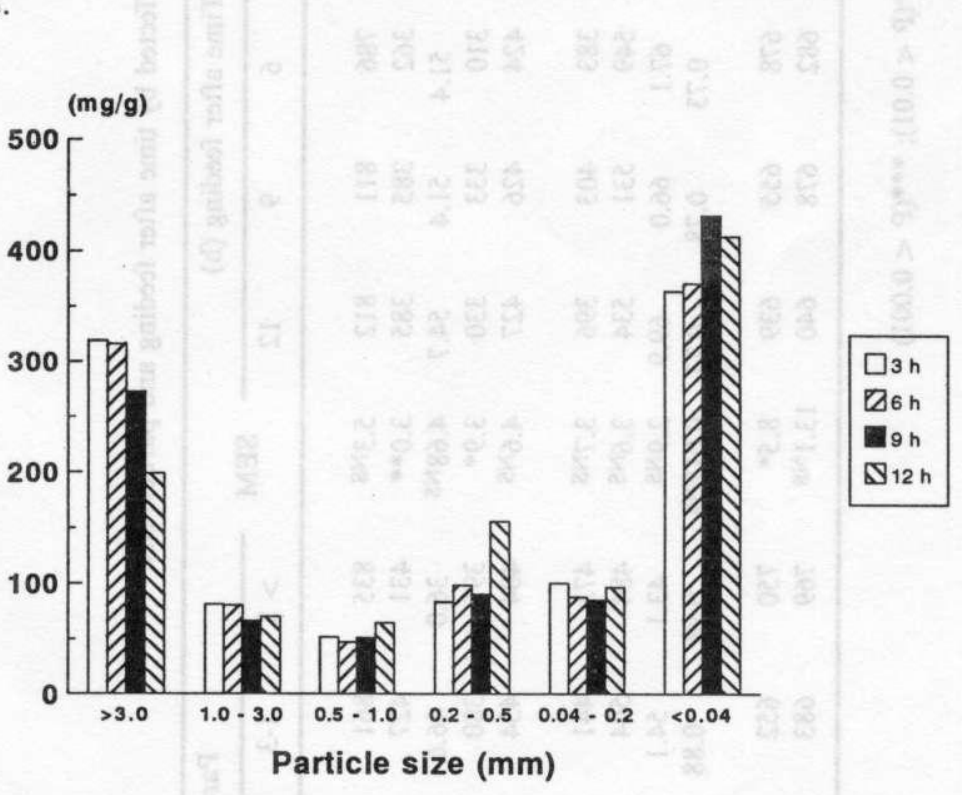

Figure 1. Change in particle size distribution of rumen contents with time after feeding.

Postprandial changes in the composition of rumen particulate matter were fairly small (Table 2$)$. The only significant $(\mathrm{P}<0.05)$ differences were in ADF and $\mathrm{C}$ content which both increased with time. The NDFD decreased $(\mathrm{P}<0.05)$ with time, and a similar trend was also observed for ADFD. On the other hand, chemical composition, NDFD and ADFD varied significantly $(\mathrm{P}<0.001)$ with particle size. NDF and ADF contents were much lower and ADL content higher in the 0.04-mm fraction than in the other fractions. The composition of NDF was also affected by the particle size; the proportion of $\mathrm{C}$ decreased and that of $\mathrm{HC}$ and ADL increased gradually as the particle size decreased. The difference was 


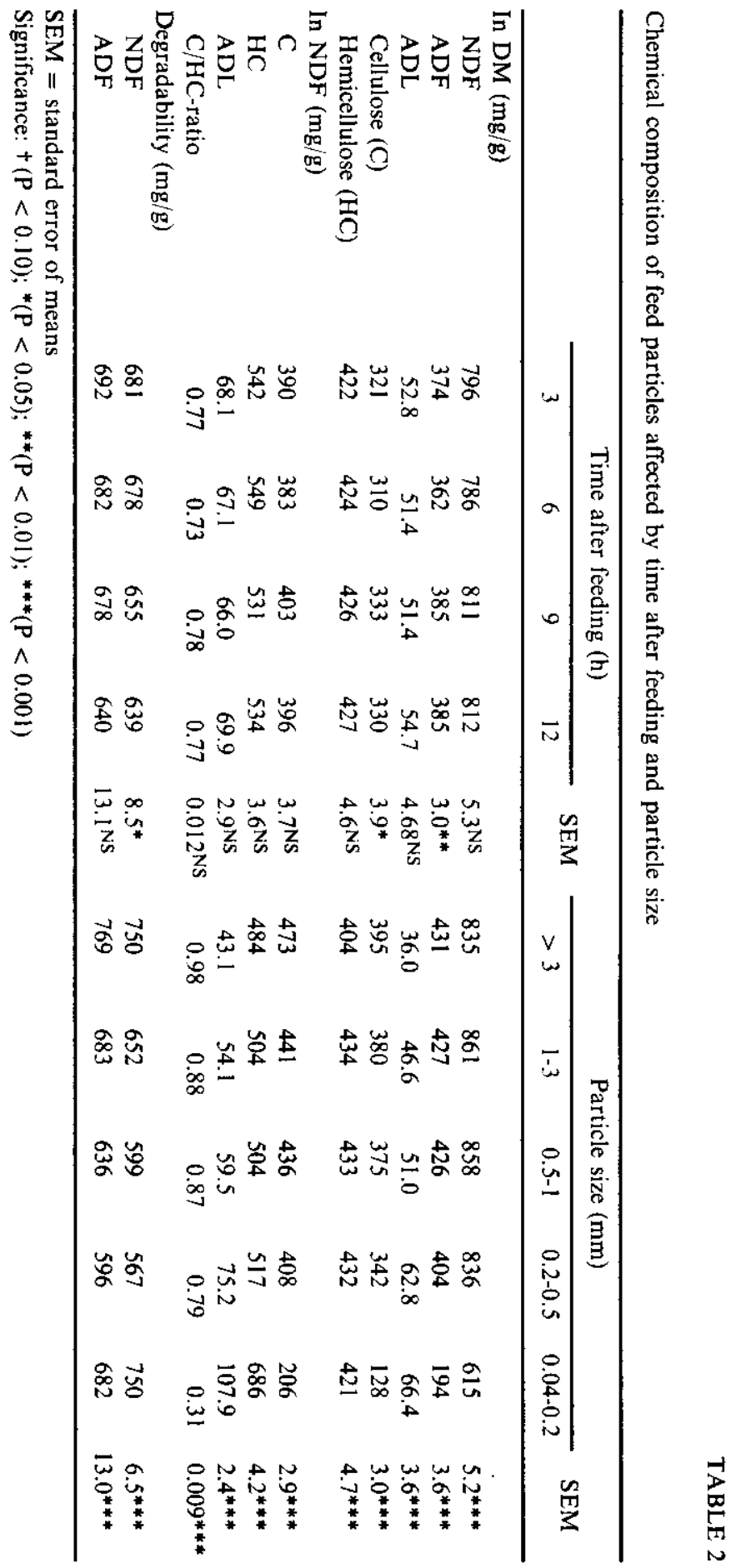


especially distinct between the $0.02-$ and $0.04-\mathrm{mm}$ fractions. The NDFD decreased from $750 \mathrm{mg} \mathrm{g}^{-1}$ in the $3-\mathrm{mm}$ fraction to $567 \mathrm{mg} \mathrm{g}^{-1}$ in the $0.2-\mathrm{mm}$ fraction. In the smallest fraction $(0.04 \mathrm{~mm})$ NDFD was similar to that in the 3-mm fraction but ADFD was lower.

There was a significant $(\mathrm{P}<0.001)$ time $\mathrm{x}$ particle size interaction in NDFD (Fig. 2). Among the four largest fractions, the smaller the particle size the later the maximum in NDFD was reached. Among the four largest particle fractions, the NDFD and composition were highly correlated (ADL: -0.847 ; C: $0.623 ; \mathrm{HC}$ : -0.667 ; ADL/NDF: -0.825 ; C/NDF: 0.799; HC/NDF: -0.590).

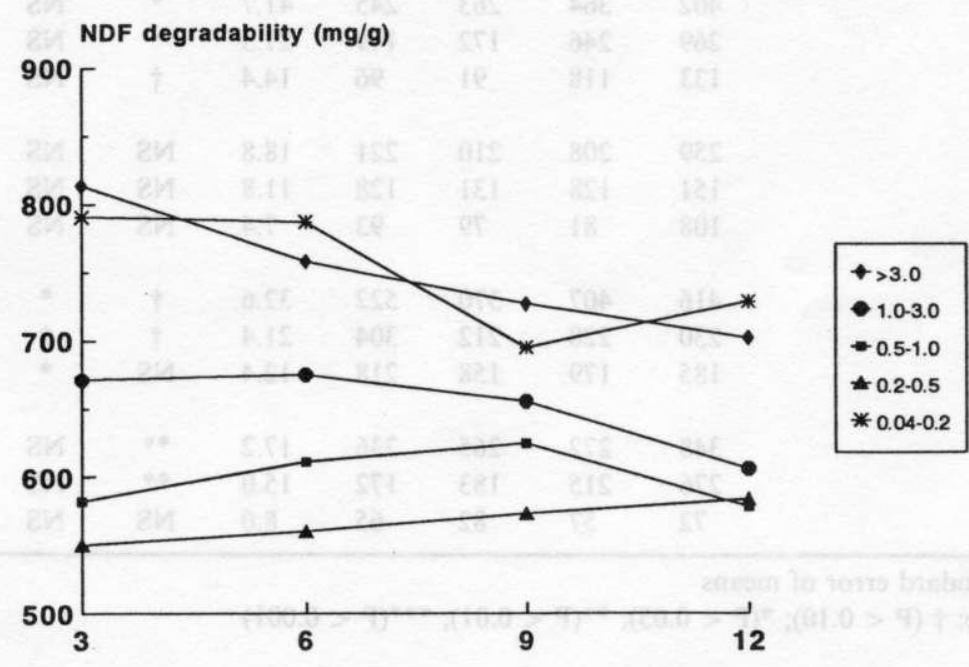

Time after feeding (h)

Figure 2. Changes in potential NDF digestibility with particle size and time after feeding.

The distribution of NDF in various particle pools is shown in Table 3. The greatest reduction with time after feeding occurred in the total NDF and DNDF retained by the $3.0 \mathrm{~mm}$ sieve (linear trend $\mathrm{P}<0.001$ ). The amount of NDF in the 0.04-mm fraction also decreased linearly with time. As a result of decreasing NDFD with time, relative diurnal changes in the amount of rumen NDF retained by 3.0 and $1.0-\mathrm{mm}$ sieves were greater for digestible than for indigestible fraction. The average rate of disappearance of particles was 96.7 and $17.4 \mathrm{~g} \mathrm{~h}^{-1}$ for NDF retained by the 3.0 and $1.0-\mathrm{mm}$ sieves.

The effects of time and particle size on particle-associated enzyme activities are shown in Table 4. Both CMCase and xylanase activities increased with time (linear effect $P<0.05$ ). The enzyme acitivities increased gradually as the particle size decreased from $>3.0 \mathrm{~mm}$ to $0.2-0.5 \mathrm{~mm}$, and increased to $3.0-4.5$-fold in 
TABLE 3

The effect of time after feeding on distribution of NDF in various fractions

\begin{tabular}{|c|c|c|c|c|c|c|c|c|}
\hline \multirow{2}{*}{ Particle size $(\mathrm{mm})$} & \multicolumn{4}{|c|}{ Time after feeding (h) } & \multirow{2}{*}{ SEM } & \multicolumn{3}{|c|}{ Significance of effect } \\
\hline & 3 & 6 & 9 & 12 & & Linear & Quadr. & Cubic \\
\hline \multicolumn{9}{|l|}{$>3.0$} \\
\hline Total & 1534 & 1391 & 1089 & 664 & 66.4 & $* * *$ & $\dagger$ & NS \\
\hline DNDF & 1248 & 1058 & 787 & 469 & 50.2 & $* * *$ & NS & NS \\
\hline INDF & 287 & 333 & 302 & 197 & 21.8 & $*$ & $*$ & NS \\
\hline \multicolumn{9}{|l|}{$1.0-3.0$} \\
\hline Total & 402 & 364 & 263 & 245 & 41.7 & $*$ & NS & NS \\
\hline DNDF & 269 & 246 & 172 & 149 & 27.5 & $*$ & NS & NS \\
\hline INDF & 133 & 118 & 91 & 96 & 14.4 & $\dagger$ & NS & NS \\
\hline \multicolumn{9}{|l|}{$0.5-1.0$} \\
\hline Total & 259 & 208 & 210 & 221 & 18.8 & NS & NS & NS \\
\hline DNDF & 151 & 128 & 131 & 128 & 11.8 & NS & NS & NS \\
\hline INDF & 108 & 81 & 79 & 93 & 7.4 & NS & NS & NS \\
\hline \multicolumn{9}{|l|}{$0.2-0.5$} \\
\hline Total & 416 & 407 & 370 & 522 & 32.6 & $\dagger$ & $*$ & NS \\
\hline DNDF & 230 & 228 & 212 & 304 & 21.4 & $\dagger$ & $\dagger$ & NS \\
\hline INDF & 185 & 179 & 158 & 218 & 12.4 & NS & $*$ & NS \\
\hline \multicolumn{9}{|l|}{$0.04-0.2$} \\
\hline Total & 348 & 272 & 265 & 236 & 17.2 & $* *$ & NS & NS \\
\hline DNDF & 276 & 215 & 183 & 172 & 15.0 & $* *$ & NS & NS \\
\hline INDF & 72 & 57 & 82 & 65 & 8.0 & NS & NS & + \\
\hline
\end{tabular}

SEM = standard error of means

Significance: $\dagger(\mathrm{P}<0.10) ;{ }^{*}(\mathrm{P}<0.05) ; * *(\mathrm{P}<0.01) ;{ }^{* * *}(\mathrm{P}<0.001)$

the $0.04-\mathrm{mm}$ fraction as compared with $0.2-\mathrm{mm}$ fraction. Time $\mathrm{x}$ size interaction both in CMCase and xylanase activity was significant $(P<0.01)$. Xylanase increased from 20.3 to 44.7 between $3-12 \mathrm{~h}$ post-feed in the $3-\mathrm{mm}$ fraction while the variation in smaller particles was much less; e.g. 32.4 to 46.8 in the $0.5-\mathrm{mm}$ fraction and 40.0 to 47.7 in the $0.2-\mathrm{mm}$ fraction. The content of neutral-detergent (ND) solubles of particulate DM was highly correlated with CMCase $(r=0.953)$ and xylanase $(r=0.899)$.

\section{DISCUSSION}

The feeding level used $\left(65 \mathrm{~g} \mathrm{DM}(\mathrm{kg} \mathrm{LW})^{-1}\right)$ was restricted below to appetite to ensure that the meals were eaten in a short period. Rapid loss of DM from the rumen during the $3 \mathrm{~h}$ after feeding agrees with the observations of Moseley and Jones (1984) and Aitchison et al. (1986). Since the frequency of reticulum contractions increases during eating (Balch, 1971), greater DM loss during this 
I

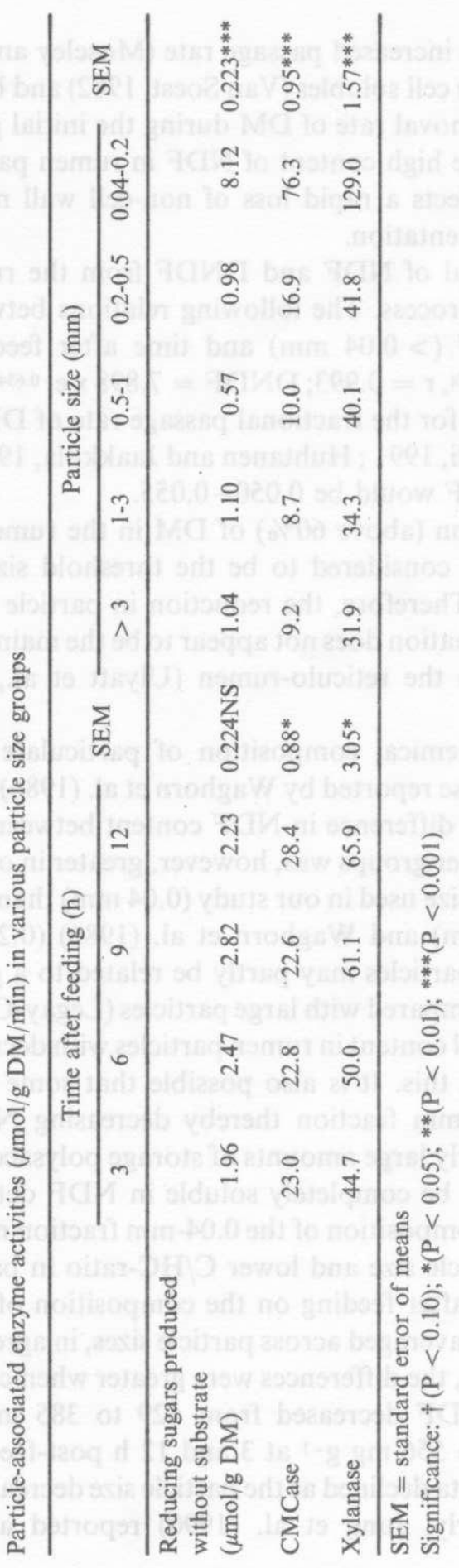


period may be due to increased passage rate (Moseley and Jones, 1984). Rapid fermentation of forage cell solubles (Van Soest, 1982) and barley starch may also explain the higher removal rate of DM during the initial period after feeding in the present study. The high content of NDF in rumen particulate matter at $3 \mathrm{~h}$ after feeding also reflects a rapid loss of non-cell wall material either due to solubilization or fermentation.

The rate of removal of NDF and DNDF from the rumen appeared to be a more exponential process. The following relations between rumen pool size of NDF and DNDF ( $>0.04 \mathrm{~mm})$ and time after feeding were calculated: $\mathrm{NDF}=8.191 \times \mathrm{e}^{-0.0450 \mathrm{t}}, \mathrm{r}=0.993 ; \mathrm{DNDF}=7.898 \times \mathrm{e}^{-0.654 \mathrm{t}}, \mathrm{r}=0.996$. Using the value of $0.010-0.015$ for the fractional passage rate of DNDF from the rumen (Huhtanen and Khalili, 1991 ; Huhtanen and Jaakkola, 1992) the fractional rate of digestion of DNDF would be $0.050-0.055$.

The large proportion (above $60 \%$ ) of DM in the rumen was below the size $(<1.0 \mathrm{~mm})$ which is considered to be the threshold size to particle passage (Poppi et al., 1980). Therefore, the reduction in particle size by comminution during eating or rumination does not appear to be the main rate limiting factor in clearing digesta from the reticulo-rumen (Ulyatt et al., 1986; Kennedy and Murphy, 1988).

The changes in chemical composition of particulate DM with size were broadly similar to those reported by Waghorn et al. (1986) and Jung et al. (1990) for lucerne diets. The difference in NDF content between the smallest particle size group and the other groups was, however, greater in our study. This may be due the smaller mesh size used in our study $(0.04 \mathrm{~mm})$ than in the studies of Jung et al. (1990) $(0.15 \mathrm{~mm})$ and Waghorn et al. (1986) $(0.25 \mathrm{~mm})$. Lower NDF content in the small particles may partly be related to a greater attachment of bacteria to small as compared with large particles (Legay-Carmier and Bauchart, 1989). An increasing $\mathrm{N}$ content in rumen particles with decreasing size (Waghorn et al., 1986) supports this. It is also possible that some rumen protozoa was included in the $0.04-\mathrm{mm}$ fraction thereby decreasing NDF content. Rumen protozoa contains fairly large amounts of storage polysaccharides (Czerkawski, 1986) which may not be completely soluble in NDF detergent but soluble in ADF. The different composition of the $0.04-\mathrm{mm}$ fraction may also be associated with the smaller particle size and lower $\mathrm{C} / \mathrm{HC}$-ratio in barley than in silage.

The effect of time after feeding on the composition of particulate DM and NDF was small when averaged across particle sizes, in agreement with Waghorn et al. (1986). However, the differences were greater when calculated from rumen NDF pool, e.g. C/NDF decreased from 429 to $385 \mathrm{mg} \mathrm{g}^{-1}$ and $\mathrm{HC} / \mathrm{NDF}$ increased from 523 to $556 \mathrm{mg} \mathrm{g}^{-1}$ at 3 and $12 \mathrm{~h}$ post-feeding.

The NDFD of digesta declined as the particle size decreased from $>3.0 \mathrm{~mm}$ to $0.2-0.5 \mathrm{~mm}$. Similarly, Jung et al. (1990) reported a lower in vitro DM 
digestibility for small than for large particles. This relationship may reflect the fermentation history of the particles. Higher NDFD of the 0.04-mm fraction in the present study may be related to a greater particle loss from the bags during the 12-d ruminal incubation. Although chewing during ingestion and rumination are of major importance in particle size reduction, particle size has also decreased during in situ incubation (Nocek and Kohn, 1988). Among the particle size groups $\geqslant 0.2 \mathrm{~mm}$, NDFD was influenced by the composition of NDF with ADL being the major determinant of NDFD. The C/NDF-ratio was positively and that of HC/NDF negatively correlated with NDFD. This is consistent with the greater rate of removal of $\mathrm{C}$ than that of $\mathrm{HC}$ from the rumen $\left(0.058 \mathrm{vs} .0 .038 \mathrm{~h}^{-1}\right)$. These observations agree with higher ruminal and total digestibility of $\mathrm{C}$ than that of $\mathrm{HC}$ in cattle given similar diets to that used in the present study (Jaakkola et al., 1991; Khalili and Huhtanen, 1991).

Significant time $x$ particle size interaction in NDFD may be related to the changes in the age and composition of particles with time. The pool size of $>3.0$ $\mathrm{mm}$ particles increases during eating relatively more than that of other fractions, and consequently NDFD increases more due to higher NDFD of feed than ruminal digesta (Jung et al., 1990). On the other hand, later particle size reduction by rumination provides recently ingested feed particles from the 3-mm fraction to the other fractions thereby increasing their NDFD.

Although ingested plant material is rapidly colonized in the rumen (Cheng et al., 1984), particle-associated enzyme activities increased between $3-12 \mathrm{~h}$ after feeding, in agreement with Williams et al. (1989). They observed that the number of microorganisms attached to digesta particles were similar at 2 and $20 \mathrm{~h}$ after feeding, and the increases in enzyme activity did not occur as a result of increased population but were due to increased activities in an attached population. Greater diurnal variation in enzyme activities, NDFD and also NDF pool size in the 3-mm fraction than in the $0.5-$ and $0.2-\mathrm{mm}$ fractions indicates that most of ingested forage enters this fraction, and that particle breakdown proceeds rapidly. On the other hand, the amounts of NDF entering the small particle pools from large particles by comminution during rumination, and the amounts leaving by digestion and passage were almost equal even although the animals were fed twice daily.

The higher enzyme activities in the $0.04-\mathrm{mm}$ fraction than in the other fractions may relate to the increased surface area. Bacterial attachment is proportional to the surface area exposed to attack (King, 1966). It is also possible that rumen protozoa included in this franction had celluloytic activity (Coleman, 1985). The positive correlation between the enzyme activities and the content of ND solubles support the conclusion of Kennedy and Milligan (1988) that the latter in small, water-extracted particles might approximate DM of adherent microbes. Except for the $0.04-\mathrm{mm}$ fraction, the content of ND solubles in 
particulate DM was lower than the values reported for microbila DM in particles by Craig et al. (1987). They used ${ }^{15} \mathrm{~N}$ as a microbial market to estimate microbial contamination.

\section{CONCLUSIONS}

The data presented here indicated that ND solubles disappeared rapidly from the particulate matter in the rumen. Chemical compositon of particulate DM varied with particle size. These changes were related to the availability of the fibre in rumen fermentation. The changes in the composition of NDF suggested that the rates of digestion of fibre components were different. The gradual increase in particle-associated enzyme activities with time after feeding and decreasing particle size suggested that a relatively long period is needed to establish maximum activity of the adherent population.

\section{REFERENCES}

Aitchison E.M., Gill M., Dhanoa M.S., Osbourn D.F., 1986. The effect of digestibility and forage species on the removal from the rumen and voluntary intake of hay by sheep. Br. J. Nutr. 56, $463-476$

Balch C.C., 1971. Proposal to use time spent chewing as an index of the extent to which ruminants possess the physical property of fibrousness characteristics of roughages. Br. J. Nutr. 26, $383-392$

Cheng K.J., Stewart C.S., Dinsdale D., Costerton J.W., 1984. Electron microscopy of bacteria involved in the digestion of plant cell walls. Anim. Feed Sci. Technol. 10,93-120

Coleman G.S., 1985. The cellulase content of 15 species of entodiniomorphid protozoa, mixed bacteria and plant debris isolated from the ovine rumen. J. agric. Sci., Camb. 104, $349-360$

Craig W.M., Broderick G.A., Ricker R.B., 1987. Quantitation of microorganisms associated with the particulate phase of ruminal digesta. J. Nutr. 117, 56-62

Czerkawski J.W., 1986. An Introduction to Rumen Studies. Pergamon Press. Oxford, pp. 236

Forsberg C.W., Lam K., 1977. Use of adenosine 5'-triphosphate as an indicator of the microbiota biomass in rumen contents. Appl. Environ. Microbiol. 33, 528-537

Gerson T., King A.S.D., Kelly, K.E., Kelly W.J., 1988. Influence of particle size and surface area on in vitro rates of gas production, lipolysis of triacylglyserol and hydrogenation of linoleic acid by sheep rumen digesta or Ruminococcus flavefaciens. J. agric. Sic., Camb. 110, 31-37

Goering H.R., Van Soest P.J., 1970. Forage fibre analyses. Agriculture Handbook No. 39. U.S. Dept. Agric. Washington

Huhtanen P., Khalili H., 1991. Sucrose supplements in cattle given grass silage-based diet. 3. Ruman poll size and digestion kinetics. Anim. Feed Sci. Technol. 33, 275-287

Huhtanen, P., Jaakkola S., 1992. The effect of the forage preservation method and the proportion of concentrate on digestion of cell wall carbohydrates and rumen digesta pool size in cattle. Grass Forage Sci. (In press)

Huhtanen P., Khalili H., 1992. The effect of sucrose supplements on particle-associated carbocymethylcellulase (EC 3.2.1.4) and sylanase (EC 3.2.1.8) activities in catte given grass-silage-based diet. Br. J. Nutr. 67, 245-255

Jaakkola S., Huhtanen P., Hissa K., 1991. The effect of cell wall degrading enzymes of formic acid on fermentation quality and digestion of grass silage by cattle. Grass Forage Sci. 46, 75-87

Jung H-J.G., Åman P., Graham H., 1990. Profile of fibre composition in lucerne (Medicago sativa) hay and rumen digesta as influenced by particle size and time after feeding. J. Sci. Food Agric. $51,411-416$ 
Kennedy P.M., Murphy M.R., 1988. The nutritional implications of differential passage of particles through the ruminant alimentary tract. Nutr. Res. Rev. 1, 189-208

Khalili H., Huhtanen P., 1991. Suctose supplements in cattle given grass silage-based diet. 2. Digestion of cell wall carbohydrates. Anim. Feed Sci. Technol. 33, 263-274

King K.W., 1966. Enzymatic degradation of crystaline hydrocellulose. Biochem. Biophys. Res. Commun. 24, 295

Legay-Carmier F., Bauchart D., 1989. Distribution of bacteria in the rumen contents of dairy cows given a diet supplemented with soya- bean oil. Br. J. Nutr. 61, 725-740

Moseley G., Jones J.R., 1984. The physical digestion of perennial ryegrass Lolium perenne) and white clover (Trifolium repens) in the foregut of sheep. Br.J. Nutr. 52, 381-390

Murphy M.R., Nicoletti J.M., 1984. Potential reduction of forage and rumen digesta particle size by microbial action. J. Dairy Sci. 67, 1221-1226

Nocek J.E., Kohn R.A., 1988. In situ particle size reduction of alfalfa and timothy hay as influenced by form and particle size. J. Dairy Sci. 71, 932-945.

Poppi D.P., Norton B.W., Minson D.J., Hendricksen R.E., 1980. The validity of the critical size in theory for particles leaving the rumen. J. agric. Sci., Camb. 94, 275-280

Silva A.T., Wallace R.J., Ørskov E.R., 1987. Use of particle-bound microbial activity to predict the rate and extent of degradation in the rumen. Br. J. Nutr. 57, 89-98- $+07-415$

Ulyatt M.J., Bellow D.W., John A., Reid C.S.W., Waghorn G.C., 1986. Contribution of chewing during eating and rumiantion to the clerance of digesta from the reticulorumen. In: L.P. Milligan, W.L. Grovum, A. Dobson (Editors) Control of Digestion and Metabolism in Ruminants. Prentice Hall, Englewood, Cliffs, NJ, pp. 498-515

Van Soest P.J., 1982. Nutritional Ecology of Ruminants. O \& B Books, Inc. Corvallis, OR

Waghorn G.C., Reid C.S., Ulyatt M.J., John A., 1986. Feed comminution, particle composition and distribution between the four compartments of the stomach in sheep fed chaffed lucerne hay at two feeding frequencies and intake levels. J. agric. Sci., Camb. 106, 287-296

Williams A.G., Withers S.E., Strachan N.H., 1989. Postprandial variations in the activity of polysaccharide-degrading enzymes in microbial populations from the digesta solids and liquor fractions of rumen contents. J. Appl. Bacteriol. 66, 15-26

\section{STRESZCZENIE}

\section{Skład, strawność i aktywność enzymów związanych z cząstkami paszy w treści żwacza w zależności od wielkości cząstek i czasu po karmieniu}

Doświadczenie przeprowadzono na bykach karmionych dwa razy dziennie dawką składającą się z kiszonki z trawy i śruty jęczmiennej (70:30). Całą treść żwacza wybierano ręcznie przez przetokę żwacza przed karmieniem oraz w 3,6 i 9 godzin po karmieniu. Przerwa między kolejnym wybieraniem treści wynosila 27 godz. Próby treści żwacza rozdzielono ,na mokro" na sitach na frakcje zawierające cząstki o różnej wielkości. Największe dobowe zmiany w ilości NDF stwierdzono we frakcji cząstek większych niż $3 \mathrm{~mm}$. Male cząstki $(0,04-0,2 \mathrm{~mm})$ zawierały, w porównaniu z cząstkami dużymi, mniej NDF i celulozy a więcej ADL. Ilość potencjalnie strawnego NDF, oznaczonego podczas 288 godzinnej inkubacji woreczków w żwaczu, zmniejszał się wraz ze zmniejszaniem się wielkości cząstek, z wyjątkiem frakcji $0,04 \mathrm{~mm}$. Strawność NDF była dodatnio skorelowana $\mathrm{z}$ udziałem $\mathrm{w}$ niej celulozy a ujemnie $\mathrm{z}$ udziałem ADL $\mathrm{i}$ hemicelulozy. Stwierdzono nieznaczny wpływ czasu po karmieniu na skład chemiczny SM treści żwacza, natomiast strawność NDF malala wraz z wiełkością cząstek. Aktywność karboksymetylcelulozy i ksylanazy zwiększała się wraz ze zmniejszaniem się wielkości cząstek. Aktywność ta byla 3-9 razy większa dla frakcji cząstek $0,04 \mathrm{~mm}$ niż dla pozostałych. Stwierdzono dodatnią zależność pomiędzy aktywnością enzymów i zawartością związków rozpuszczalnych w obojętnym detergencie. 